\title{
EMPAT VARIABEL PENTING YANG MEMPENGARUHI KINERJA GURU MADRASAH IBTIDAIYAH DI KOTA MANADO
}

\author{
Rivai Bolotio \\ STAIN Manado \\ rivaibolotio@yahoo.co.id
}

\begin{abstract}
Abstrak
Artikel ini merupakan rangkuman dari hasil penelitian yang berhubungan dengan empat variabel penting yang mempengaruhi kinerja guru Madrasah Ibtidaiyah di Kota Manado. Keempat variabel dimaksud adalah budaya organisasi, pemahaman agama, pengalaman ibadah dan etos kerja.

Metode yang digunakan dalam penelitian ini adalah metode kuantitatif korelasional. Penelitian ini dilaksanaakn di Madrasah Ibtidaiyah di Kota Manado dengan sampel 96 yang diambil dari 127 guru dengan menggunakan proportional stratified random sampling. Pengumpulan data dilakukan dengan menggunakan instrument tes dan nontes. Tes digunakan untuk mengumpulkan data tentang pemahaman agama dan nontes digunakan untuk mengumpulkan data budaya organisasi, pengamalan ibadah, etos kerja dan kinerja. Data yang terkumpul kemudian dianalisis dengan menggunakan analisis deskriptif dan analisis jalur.

Hasil penelitian ini menunjukkan bahwa budaya organisasi berpengaruh langsung positif terhadap kinerja guru. Pemahaman agama berpengaruh langsung positif terhadap kinerja guru. Pengamalan ibadah berpengaruh langsung positif terhadap kinerja guru dan etos kerja berpengaruh langsung positif terhadap kinerja guru. Untuk meningkatkan kinerja guru maka upaya yang dilakukan terkait dengan empat variabel tersebut di antaranya menciptakan budaya organisasi yang kondusif, meningkatkan pemahaman agama guru dengan memperbaharui pengetahuan agama, meningkatkan pengamalan ibadah guru dengan memperkuat keimanan dan ketaqwaan kepada Tuhan, dan meningkatkan kesadaran diri, bahwa ketaatan dan kesungguhan dalam mengamalkan ibadah.
\end{abstract}




\section{Kata Kunci : Budaya organisasi, pemahaman agama, pengamalan ibadah, etos kerja dan kinerja.}

\section{A. Pendahuluan}

Lembaga pendidikan Islam dalam hal ini madrasah dan pesantren merupakan institusi pendidikan yang memiliki keterkaitan dengan berbagai hal, baik dari segi manajemen, sumber daya manusia, kepemimpinan maupun permasalahan lainnya. Elemen-elemen tersebut di atas, merupakan faktor kunci dalam peningkatan pelayanan kepada para penggunanya. Berangkat dari pemikiran tersebut di atas, maka lembaga pendidikan Islam dituntut untuk bisa memberikan pelayanan yang baik kepada para penggunanya.

Lembaga pendidikan Islam sebagai organisasi nirlaba senantiasa mengalami perkembangan dan perubahan-perubahan. Di sisi lain, lembaga pendidikan Islam juga mengalami berbagai macam tantangan baik yang berasal dari dalam organisasi maupun dari luar.

Dalam menghadapi berbagai tantangan dan perubahan tersebut, diperlukan adanya pengelolaan asset yang dimiliki terutama sumber daya manusia agar organisasi tetap eksis dan mampu menyesuaikan diri dengan perkembangan zaman. Untuk mengelola sumber daya manusia diperlukan seni mengelola yang baik. Dengan demikian, aspek manajerial menjadi sebuah hal yang sangat penting.

Dengan demikian pengelolaan lembaga pendidikan Islam baik itu tenaga administrative maupun tenaga pengajar merupakan faktor utama dalam penyelenggaraan fungsi madrasah sebagai lembaga pendidikan. Sarana/prasarana, pendanaan, perangkat peraturan akan menjadi tidak produktif tanpa didukung guru yang cakap dan berdedikasi tinggi. Guru yang memiliki kinerja yang baik, akan membantu organisasinya untuk mencapai tujuan secara maksimal.

Kinerja merupakan prestasi kerja seseorang dalam melaksanakan tugasnya sesuai dengan tanggung jawab yang diembannya. Ada banyak hal yang mempengaruhi kinerja seseorang. Di antara faktor yang mempengaruhi kinerja adalah budaya organisasi, etos kerja dan faktor lain yang berhubungan dengan aspek non materi yaitu pemahaman agama dan pengamalan ibadah. 
Dalam pandangan Robbins (2001), budaya organisasi adalah sistem makna bersama terhadap nilai-nilai primer yang dianut bersama dan dihargai organisasi, yang berfungsi menciptakan pembedaan yang jelas antar satu organisasi dengan organisasi lainnya, menciptakan rasa identitas bagi para anggota organisasi, mempermudah timbulnya komitmen kolektif terhadap organisasi, meningkatkan kemantapan sistem sosial, serta menciptakan mekanisme pembuat makna dan kendali yang memandu membentuk sikap dan perilaku para anggota organisasi.

Jerald Grennberg dan Robert A. Baron (1997), mendefinisikan buday organisasi sebagai kerangka kerja kognitif yang terdiri dari sikap, nilai-nilai, norma perilaku dan harapan yang diterima bersama oleh anggota organisasi. Robert Kreitner dan Angelo Kinicki (2001) mendefinisikan budaya organisasi adalah nilai-nilai dan keyakinan bersama yang menjadi dasar bagi identitas sebuah perusahaan. Sedangkan Mangkunegara (2005) mengatakan bahwa, budaya organisasi adalah seperangkat asumsi atau sistem keyakinan, nilai-nilai dan norma yang dikembangkan dalam organisasi yang dijadikan pedoman tingkah laku bagi anggota-anggotanya untuk mengatasi masalah adaptasi eksternal dan integrasi internal. Robert Vecchio (2006) menjelaskan bahwa budaya organisasi adalah filosofi yang mendasari kebijakan organisasi, aturan main untuk bergaul dan perasaan atau iklim yang dibawa oleh persiapan fisik organisasi. Adapun menurut Wibowo (2011), budaya organisasi adalah filosofi dasar organisasi yang memuat keyakinan, norma-norma, dan nilai-nilai bersama yang menjadi karakteristik inti tentang bagaimana cara melakukan sesuatu dalam organisasi.

Dalam lingkungan lembaga pendidikan, budaya organisasi bermuara pada tujuan menghasilkan lulusan yang berguna dan bisa bersaing di dunia kerja. Budaya organisasi sebagai sistem internal dan sistem eksternal sosial. Budaya organisasi tercermin dari inisiatif individu, toleransi terhadap risiko, pengarahan, integrasi, dukungan manajemen, pengawasan, identitas, sistem penghargaan serta toleransi terhadap konflik. Sementara itu, kinerja merupakan ukuran keberhasilan seseorang dalam melaksanakan pekerjaannya sesuai dengan yang telah ditetapkan sebelumnya. Dalam situasi kerja, kinerja seseorang akan berbeda dengan orang lain. Pernyataan ini sejalan dengan pemikiran Soedjono yang menyebutkan bahwa 
semakin berkualitas faktor-faktor yang terdapat dalam sebuah organisasi, maka akan semakin memungkinkan berkualitasnya kinerja organisasi (Soedjono, 2005)

Dari uraian di atas dapat disimpulkan bahwa budaya organisasi akan menentukan bagaimana setiap guru dalam organisasi untuk bertindak dalam mencapai tujuan organisasi. Dengan demikian, budaya organisasi diduga berpengaruh langsung positif terhadap kinerja guru. Teori-teori yang dikemukakan tersebut didukung oleh berbagai hasil penelitian yang menyatakan bahwa budaya organisasi berpengaruh terhadap kinerja guru. Penelitian Widodo (2011) dengan judul Pengaruh Budaya Organisasi dan Motivasi Kerja terhadap Kinerja Guru menghasilkan $80,8 \%$ budaya organisasi berpengaruh terhadap kinerja guru. Ini menunjukkan bahwa jika budaya organisasi yang tercipta di suatu lembaga baik akan meningkatkan kinerja guru.

Meningkatkan kinerja guru terutama guru di lembaga pendidikan agama harus didukung dengan pemahaman tentang agama yang baik agar apa yang diajarkan dan dilakukan tidak bertentangan dengan ajaran-ajaran agama sehingga dapat diteladani oleh peserta didiknya. Agama merupakan hal yang tidak bisa dipisahkan dalam setiap kehidupan masyarakat di Indonesia. Hal ini karena beragama merupakan kewajiban setiap warga negara. Tanpa memeluk sebuah agama, maka belum lengkaplah status seseorang sebagai warna negara Republik Indonesia. Konsekuensi sebagai pemeluk agama, seorang haruslah memahami agama yang diyakininya.

Dengan status sebgaai lembaga pendidikan Islam, maka keberadaan para gurunya adalah seratus persen memeluk agama Islam. Pemahaman agama dalam Islam bisa disebut dengan Iman. Islam memiliki rukun yang berkaitan dengan iman dan dikenal dengan rukun iman. Rukun iman sendiri merupakan hal-hal yang harus diimani oleh setiap pemeluknya yaitu percaya kepada Allah, Malaikat, Kitab, Nabi dan Rasul, Hari Kiamat serta Takdir baik dan buruk.

Pemahaman agama adalah pengetahuan seorang guru menyangkut aspek ritual dan non ritual agama Islam. Paham tidaknya seseorang tentang agama dapat dilihat dari pengetahuannya tentang aspek-aspek ibadah mahdah seperti tayammum, sholat, zakat, dan haji serta aspek ibadah ghairumahdah berupa hak 
dan kewajiban seorang muslim terhadap makhluk Allah yang lain. Juga tentang munakahat, muamalah serta mawaris.

Dengan memiliki kepercayaan terhadap hal-hal di atas, maka seorang muslim dalam perilakunya harus senantiasa dibarengi dengan keyakinan bahwa segala perbuatan yang dilakukan di dunia akan mendapatkan balasan kelak di akhirat. Pernyataan ini sejalan dengan teori perilaku yang menyatakan bahwa normanorma agama merupakan motivator dan dinamisator pemunculan perilaku disiplin dalam realitas kehidupan dan nilai ilahiah sebagai supremasi refrensif. (Iffattin Nur, 2007)

Adapun variabel lain yang memiliki pengaruh terhadap kinerja adalah pengamalan ibadah. Pengamalan ibadah ialah perbuatan untuk menyatakan bakti kepada Allah SWT yang didasari oleh ketaatan menjalankan perintah-Nya dan menjauhi larangan-Nya (Muhammadiyah Djafar: 1993)

Tujuan pelaksanaan ibadah menurut pendapat Yusuf Qardhawy (1995) bukanlah untuk kepentingan Allah, tetapi untuk kemaslahatan manusia itu sendiri. Tujuan ibadah adalah untuk membebaskan manusia dari pengibadahan (ubudiyah) pada egoisme, syahwat, kelezatan-kelezatan rasa. Bertekuk lutut di hadapan tuntutan material-material dunia dan kepentingan-kepentingan pribadi. Dengan demikian pengamalan ibadah adalah proses seseorang dalam mengamalkan ajaran-ajaran Islam baik itu berupa perintah maupun meninggalkan larangan.

Pengamalan ibadah adalah prosese seseorang dalam mengamalkan ajaranajaran Islam baik yang menyangkut aspek ibadah mahdah dan ghairumahdhah. Dalam Islam, ada ibadah yang telah ditentukan cara dan waktu pelaksanaanya. Ibadah ini dikenal dengan ibadah Mahdhah. Dengan mengamalkan ibadah-ibadah tersebut, seorang muslim diharapkan akan mampu tampil sebagai pribadi yang sempurna dalam bahasa agama disebut dengan "insan kamil". Disatu sisi, ibadah itu akan mampu mencegahnya dari perbuatan-perbuatan yang negatif serta mendorongnya untuk melakukan perbuatan-perbuatan positif.

Dalam hubungannya dengan variabel etos kerja, Harsono dan Santoso (2006), menyatakan etos kerja sebagai semangat kerja yang didasri oleh nilai-nilai atau norma-norma tertentu. Selain penulis di atas, masih banyak para ahli yang 
menyatakan pengertian tentang etos kerja. Di antaranya adalah Sukriyanto (2000). Yang menyatakan bahwa etos kerja adalah suatu semangat kerja yang dimiliki oleh masyarakat untuk mampu bekerja lebih baik guna memperoleh nilai hidup mereka.

Dari pengertian di atas, tersirat bahwa etos kerja merupakan sikap positif seseorang terhadap pekerjaan yang ditekuni. Hal ini berarti orang yang memiliki etos kerja yang tinggi akan menikmati apapun pekerjaan yang ditekuninya. Sebaliknya etos kerja yang rendah dari seseorang akan menimbulkan pandangan dan sikap yang snantiasa mengeluh terhadap pekerjaan. Muaranya adalah produk yang dihasilkan tidak sesuai dengan yang diharapkan.

Secara spesifik penulisan artikel ini mengungkap berbagai macam variabel yang mempengaruhi kinerja guru Madrasah Ibtidaiyah di Kota Manado. Variabelvariabel yang dipilih adalah budaya organisasi, pemahaman agama, pengamalan ibadah, dan etos kerja.

\section{Metodologi}

Penelitian ini bertujuan untuk mengetahui gambaran dan pengaruh antara budaya organisasi, pemahaman agama, pengamalan ibadah, dan etos kerja terhadap kinerja guru. Penelitian ini merupakan penelitian kuantitatif dengan menggunakan metode penelitian survey, yakni untuk memperoleh dan menggunakan data yang bersifat kuantitatif. Instrument yang digunakan dalam penelitian ini adalah soal tes untuk mengukur pemahaman agama guru dan kuesioner untuk mengukur kinerja guru, budaya organisasi, pengamalan agama, dan etos kerja. Instrument penelitian yang dibuat sebelum digunakan dalam penelitian terlebih dahulu di uji coba untuk mengetahui validitas dan reliabilitas. Hasil uji coba instrument dikatakan valid dan reliable ( $\left.r_{h i t u n g}>r_{\text {tabel}}\right)$.

Penelitian ini dilaksanakan di Madrasah Ibtidaiyah di Kota Manado. Subjek penelitian ini adalah guru Madrasah Ibtidaiyah (MI) Kota Manado. Populasi dalam penelitian ini adalah seluruh guru Madrasah Ibtidaiyah di Kota Manado sebanyak 127 guru. Penentuan sampel dilakukan dengan cara simplerandom sampling dengan jumlah sampel sebanyak 96 orang. 
Data yang diperoleh dalam penelitian ini diolah dan dianalisis dengan teknik statistik deskriptif dan statistik inferensial. Analisis data secara deskriptif, dilakukan untuk menganalisi data yang telah terkumpul guna memperoleh gambaran karakteristik penyebaran nilai variabel yang diteliti. Analisis deskriptif digunakan dalam hal penyajian data yang dilakukan dengan langkah-langkah : perhitungan skor rata-rata (mean), modus, standar deviasi, varians, skor maksimum dan minimum. Analisis data secara inferensial dilakukan untuk menguji hipotesis dengan menggunakan analisis jalur (path ananalisys). Namun sebelum dilakukan pengujian hipotesis terlebih dahulu diadakan uji persyaratan analisis yakni uji normalitas dan linearitas serta uji model. Setelah data dikatakan memenuhi syarat normalitas dan linearitas kemudian dilanjutkan dengan uji hipotesis.

\section{Hasil Penelitian}

Data hasil penelitian kinerja guru Madrasah Ibtidaiyah di Kota Manado diperoleh skor 18. Hasil perhitungan menujukkan rata-rata 129.6; standar deviasi 3,64; mode 129, dan varians 13,27. Data penelitian untuk budaya organisasi dengan menggunakan angket menunjukkan rentang skor empirik antara 107-150, dengan rentangan skor teoretik 1-160. Hasil perhitungan menunjukkan rata-rata 124,10; simpangan baku 8,09; mode 125, dan varians 65,51. Data penelitian untuk pemahaman agama dengan diperoleh melalui tes menunjukkan rentang skor empiric antara 17-31, dengan rentangan skor teoretik 0-31. Hasil perhitungan menunjukkan rata-rata 25,23; simpangan baku 2,94; mode 25, dan varians 8,66. Data penelitian untuk pengamalan ibadah dengan diperoleh melalui angket menunjukkan rentang skor empiric antara 92-129, dengan rentangan skor 37. Hasil perhitungan menunjukkan rata-rata 115,13; simpangan baku 10,66; mode 125, dan varians 113,71. Data penelitian untuk etos kerja dengan diperoleh melalui angket menunjukkan rentang skor empiric antara 85-140, dengan rentangan skor 55. Hasil perhitungan menunjukkan rata-rata 114,11; simpangan baku 15,56; mode 115, dan varians 242,06.

Pengolahan data dalam penelitian ini menggunakan uji statistik inferensial dengan analisis jalur (path analysis). Untuk menggunakan statistik inferensial 
terlebih dahulu dilakukan uji persyaratan analisis, dengan tujuan agar hasilnya dapat digunakan untuk menarik kesimpulan. Uji persyaratan tersebut adalah uji normalitas dan linearitas. Hasil uji persyaratan normalitas dan linearitas dapat disimpulkan bahwa data terdistribusi secara normal, dan persamaan regresi yang diperoleh linear.

Pengolahan data dalam penelitian ini menggunakan uji statistik jalur (path analysis). Dari analisis dengan persamaan analisis jalur (path analysis) diperoleh hasil bahwa 1) Budaya organisasi berpengaruh langsung positif terhadap kinerja guru. 2) Pemahaman agama berpengaruh langsung positif terhadap kinerja guru. 3) Pengamalan agama berpengaruh langsung positif terhadap kinerja guru. 4) Etos kerja berpengaruh langsung positif terhadap kinerja guru. Hasil analisi dapat terlihat pada tabel berikut :

Tabel 1. Hasil Analisis Pengujian Hipotesis

\begin{tabular}{|c|c|c|c|c|c|}
\hline \multirow[t]{2}{*}{$\mathbf{n}$} & \multirow[t]{2}{*}{ Variabel } & \multirow{2}{*}{$\begin{array}{c}\text { Koefisien } \\
\text { Jalur }\end{array}$} & \multirow[t]{2}{*}{ thitung } & \multicolumn{2}{|c|}{$t_{\text {tabel }}$} \\
\hline & & & & $(\alpha=0,05)$ & $(\alpha=\mathbf{0 , 0 1})$ \\
\hline \multirow{4}{*}{96} & $\mathbf{X 1}$ & 0,355 & 4,286 & 1,98 & 2,617 \\
\hline & $\mathbf{X} 2$ & 0,274 & 3,702 & 1,98 & 2,617 \\
\hline & $\mathbf{X 3}$ & 0,133 & 3,854 & 1,98 & 2,617 \\
\hline & X4 & 0,283 & 4,796 & 1,98 & 2,617 \\
\hline
\end{tabular}

Dari hasil pengujian tersebut terlihat bahwa semua variabel befrpengaruh langsung positif terhadap kinerja guru Madrasah Ibtidaiyah di Kota Manado karena harga $t_{\text {hitung }}>t_{\text {tabel }}$. Hal ini menjelaskan bahwa untuk meningkatkan kinerja guru diperlukan variabel-variabel pendukung seperti budaya organisasi, pemahaman agama, pengamalan agama dan etos kerja.

\section{B. Pembahasan}

Hasil penelitian menunjukkan bahwa budaya organisasi berpengaruh langsung positif terhadap kinerja guru. Dengan demikian budaya organisasi merupakan variabel eksogen yang sangat penting dalam meningkatkan kinerja guru. 
Pengujian hipotesis ini mengindikasikan bahwa budaya organisasi yang baik akan berpengaruh langsung terhadap kinerja guru dalam menyelesaikan tugasnya sebagai guru. Ketika budaya organisasi yang ada di lingkungan sekolah sesuai dengan sistem dan manajemen organisasi yang baik, maka dipastikan akan mempengaruhi secraa langsung kinerja seorang guru dalam mengajar di sekolah.

Hasil penelitian ini mendukung teori hubungan antara budaya dan perilaku dalam organisasi yang dikemukakan oleh Jeff Cartwright. Dia menyebutkan bahwa keyakinan, sikap dan perilaku seseorang dapat memberikan motivasi dari budaya mereka (Jeff Cartwright, 1999, h. 11). Sementara itu Wibowo juga menekankan tingginya hubungan antara perilaku dan budaya organisasi di mana satu generasi ke generasi berikut mewariskan perilaku pembelajaran yang sesuai dengan lingkungannya. (Wibowo, 2011, h. 16).

Hasil penelitian ini sejalan dengan hasil penelitian Yumaeni Wyati Saddewisasi (2011) yang menyatakan bahwa budaya organisasi mempunyai pengaruh yang signifikan terhadap kinerja guru. Dengan demikian dapat dikatakan bahwa budaya organisasi merupakan satu faktor yang menentukan keberhasilan kerja guru karena dengan budaya organissi yang baik akan menjadi pemersatu berbagai ide, sikap, dan perilaku dari setiap anggota organisasi.

Pengujian selanjutnya diperoleh hasil adanya pengaruh langsung positif pemahaman agama terhadap kinerja guru. Kesimpulan ini menunjukkan bahwa pemahaman agama yang lahir dari kesadaran jiwa seseorang, terutama kepada para guru di sekolah/madrasah akan berpengaruh langsung terhadap kinerjanya dalam mengemban tanggung jawab sebagai tenaga pendidik di sekolah. Artinya, pemahaman agama yang baik tentu akan melahirkan pengaruh langsung terhadap kinerja sebagai seorang guru. Mempunyai pemahaman agama yang baik dan mendalam, bagi seorang guru akan menimbulkan dampak terhadap pemahaman bahwa apa yang dilakukannyasetiap hari adalah bnetuk ibadah kepada Tuhan. Oleh karena itu seorang guru yang mempunyai pemahaman agama yang baik, akan berpengaruh langsung terhadap aktivitas atau kinerjanya dalam mendidik peserta didik di sekolah. 
Adapun hasil pengujian terhadap hipotesis selanjutnya didapatkan adanya pengaruh langsung positif pengamalan ibadah terhadap kinerja guru. Seorang guru yang mempunyai pengamalan ibadah yang baik akan mmepengaruhi secara langsung aktivitas kinerjanya sebagai seorang guru. Oleh karena itu dapat dijelaskan bahwa seorang guru yang mempunyai nilai-nilai pengamalan ibadah yang baik, maka dipastikan akan mempengaruhi secara langsung kinerjanya sebagai tenaga pendidik dalam mendidik peserta didiknya di sekolah.

Hasil pengujian terhadap variabel etos kerja terhadap kinerja guru didapatkan adanya pengaruh langsung positif etos kerja terhadap kinerja guru Madrasah Ibtidaiyah di Kota Manado. Guru yang mempunyai etos kerja yang baik akan berpengaruh langsung terhadap kinerjanya sebagai seorang guru di sekolah. Etos kerja yang tinggi yang dimiliki oleh seorang guru akan mengakibatkan potensi semangat dalam dirinya meningkatkan, sehingga aktivitasnya sebagai guru dalam mendidik peserta didiknya semakin tinggi pula. Oleh karena itu, guru yang mempunyai etos kerja yang tinggi dan baik akan berpengaruh langsung terhadap kinerja guru tersebut dalam mengarahkan peserta didiknya untuk mencapai tujuan pendidikan di sekolah.

Hasil penelitian ini sejalan dengan penelitian yang dilakukan oleh Yuyun Fajriani, 2013 yang menyatakan bahwa etos kerja berpengaruh positif terhadap kinerja guru artinya jika etos kerja meningkat maka kinerja guru akan meningkat. Etos kerja guru merupakan sikap yang muncul atas kehendak dan kesadaran sendiri yang didasari oleh sistem orientasi nilai budaya terhadap kerja. Etos kerja mempunyai dasar dari nilai budaya, yang mana dari nilai budaya itulah yang membentuk etos kerja masing-masing pribadi yang mampu mempengaruhi kinerja dari diri pribadi itu sendiri.

\section{Kesimpulan}

Berdasarkan uraian-uraian yang telah dikemukakan di atas, maka diperoleh kesimpulan sebagai berikut :

1. Budaya organisasi yang baik dan sehat merupakan salaah satu penyebab terciptanya kinerja guru yang baik dalam melaksanakan tugas dan 
fungsinya. Menciptakan budaya organisasi yang baik dan sehat di lingkungan madrasah, dapat diupayakan melalui pengarahan secara intensif, inisiatif individu dalam bekerja, dukungan manajemen yang sehat, pengawasan yang kredibel, sistem penghargaan yang adil serta pengelolaan manajemen konflik yang bervisi masa depan.

2. Guru yang memilki pengetahuan dan pemahaman agama yang baik, berpengaruh positif terhadap kinerjanya. Artinya, apabila setiap guru memahami secara benar nilai-nilai kebaikan dan kebenaran yang terdapat pada agama yang diyakininya, maka hal ini sangatlah bermanfaat terhadap guru itu sendiri. Sebab, setiap perbuatan baik dan benar yang dilakukannya merupakan bagian dari perintah agamanya.

3. Pengamalan ibadah secara maksimal berpengaruh positif terhadap kinerja guru. Artinya, seorang guru yang menyadari bahwa membimbing, mendidik, dan melatih murid-muridnya merupakan mafestasi dari beribadah kepada Allah SWT, maka hal ini akan mengakibatkan terwujudnya kinerja yang baik dalam menyelesaikan tugas dan fungsinya.

4. Guru yang memiliki etos kerja yang tinggi berpengaruh positif terhadap kinerjanya. Artinya, seorang guru yang memiliki sikap positif terhadap pekerjaan yang ditekuninya, maka apapun pekerjaan yang ditekuninya akan dinikmatinya. Sebaliknya etos kerja yang rendah dari seorang guru akan menimbulkan pandangan dan sikap yang senantiasa mengeluh terhadap pekerjaan. Muaranya adalah produk yang dihasilkan tidak sesuai dengan yang diharapkan. Mewujudkan etos kerja guru yang baik antara lain dapat diupayakan melalui peningkatan keahlian interpersonal dan emosional power dengan cara membuat pelatihan motivasi yang terencana dan berkelanjutan. 


\section{Daftar Pustaka}

Anwar Prabu Mangkunegara. Perilaku dan Budaya Organisasi. Bandung: Refika Aditama, 2005.

Armstrong Karen, A History of God: the 4,000 year Quest of Judaism, Christianity and Islam, (Terjemahan Zaimul Am, Sejarah Tuhan: Kisah Pencarian Tuhan Yang Dilakukan oleh Orang-Orang Yahudi, Kristen dan Islam selama 4000 Tahun), Bandung: Mizan, 2003.

Elizabeth K. Nottingham, Agama dan Masyarakat: Suatu Pengantar Sosiologi Agama. Jakarta: Rajawali, 1985.

Greenberg, Jerald And Robert A. Baron, Behavior in Organization, New Jersey: Prentice Hall, 1997.

Hamka, Filsafat Ketuhanan, Surabaya: Karunia, 1987.

Harun Nasution, Islam Ditinjau dari Berbagai Aspeknya, Jakarta: Universitas Indonesia Press (UIP), 2001.

Iffattin Nur, Revitalisasi Nilai-Nilai Syariah, Jurnal Hukum Islam, STAIN tulungagung, Volume 9, Nomor 02, November, 2007.

Mohammad Nasir Oemar, Ethics in Islam: A Critical Survey. (Islamiyyat, 2010).

Said Hawwa, Al Islam, Jakarta: Gema Insani Press, 2004.

Sinamo, J. Etos Kerja Profesional di Era Digital Global (Jakarta: Penerbit Institut Darma Mahardika, 2002).

Jalaludin, Psikologi Agama: Sebuah Pengantar, Bandung: Mizan, 2005).

Kreitner Robert And Angelo Kinicki, Organizational Behavior, New York: Mc Graw-Hill Higer Education, 2001. 
Muhammadiyah Djafar, Pengantar Ilmu Fikih, Jakarta: Kalam Mulia, Cet. Ke-I, 1993.

Paul Heelless, "Work Ethics, soft capitalism and 'the turn to life"” on John Allen, Cultural Economy: Cultural Analysis and Commercial Life (Sage Publications (CA), 2002).

Qhardawy Yusuf, Al Khosoish Al Amah Li Al Islam, Surabaya: Risalah Gusti, 1995).

Robert P. Vecchio, Organizational Behavior. Orlando: Harcourt Brace \& Company, 2006.

Robbins. Stephen P, Organizational Behavior. New Jersey: Prentice Hall International, 2001.

Wibowo, Manajemen Kinerja. Jakarta: Raja Grafindo Perkasa, 2011.

Widodo, Pengaruh Budaya Organisasi dan Motivasi terhadap Kinerja Guru Jurnal Pendidikan Penabur No.16/Tahun ke-10/Juni 2011.

Yumaeni, Wyati Saddewisasi, Pengaruh Budaya Organisasi dan Konsep diri terhadap Kinerja Guru Jurnal Riset Ekonomi dan Bisnis Vol. 1. 2011.

Yuyun Fajriani, Pengaruh Gaya Kepemimpinan Kepala Sekolah dan Etos Kerja Guru terhadap Kinerja Guru (Studi Pada Al Azhar Syifa Budi Solo), Jurnal Penelitian, UNS, Vol. 1 No. 1. 2013. 